\title{
COOPERATIVES AND INCOME TAXES
}

\author{
WILFRID E. RUMBLE*
}

Cooperative associations are subject to every real and personal property tax and almost every other type of tax, in the same way and to the same extent as ordinary private business corporations. It is in respect to income taxes that their treatment is different. It is to that point that this article is addressed.

In order fairly to judge the point of view of cooperatives as to their income tax status, an understanding of the general nature of cooperatives is necessary. The cooperative corporation is essentially a group of individuals or corporations, or both, organized into corporate form for the purpose of acting collectively in the marketing of their products or the acquisition of their supplies. Almost every state in the Union has statutes expressly providing for the organization of cooperative corporations, and Congress has provided for the organization in the District of Columbia of cooperative associations of consumers. ${ }^{1}$ Most of these laws were originally enacted principally to insure to groups of farmers the right to act collectively without violating state antitrust statutes. Congress assured to cooperatives the same immunity from federal antitrust statutes by enactment of the Capper-Volstead Act in 1922. ${ }^{2}$ Neither state nor federal law grants such immunity to cooperatives in their ordinary commercial transactions and dealings.

A cooperative may be organized under the ordinary business corporation statutes of most states. The Federal Farm Board, acting under the advice of Stanley Reed, then its general counsel, now a Justice of the Supreme Court of the United States, organized its great cooperative marketing and warehousing corporations under the general corporation statutes of Delaware. There are, of course, some advantages in organization under the usual cooperative statutes, but there are also definite restrictions and disadvantages. The Minnesota General Cooperative $\mathrm{Act}^{3}$ is fairly typical. Cooperative associations organized under these statutes differ from business corporations in several important respects, among which are the following:

r. There is a limit on the amount of voting stock a member may own, a common limitation being "not more than one-twentieth of the stock outstanding";

2. Dividends on capital stock may not exceed a stated rate, such as 6 per cent per annum, and are not cumulative;

\footnotetext{
- Member of the Minnesota bar and of the firm of Doherty, Rumble, Butler, and Mitchell, St. Paul, Minnesota; counsel for several cooperative associations.

${ }^{2}$ District of Columbia Cooperative Association Act, Pub. L. No. 642, 76th Cong., 3d Sess., c. 397, approved June 19,1940 .

${ }^{2} 42$ STAT. 388,7 U.S.C. \$291 (1940).

Minn. Stat. ANn. (1945) $\$ \$ 308.05$ to 308.18 .
} 
3. Each member has one vote only, regardless of the number of shares of stock he owns; and

4. All earnings or savings remaining after payment of expenses of operation, dividends on capital stock, and provision for required reserves must be distributed.

There are in general two types of cooperative association. One engages in marketing or selling the products or property of its members and patrons (customers), and is commonly known as a marketing cooperative. Practically all cooperatives of this type are owned and controlled by farmers, and market only farm products. The other engages in purchasing or buying supplies and goods for its members and patrons, and is commonly known as a purchasing cooperative. Despite the growth in recent years of urban purchasing cooperatives, it is still true that many of the purchasing cooperatives are principally owned and controlled by farmers. Urban cooperatives of this type are frequently referred to as consumer cooperatives. Some farmer-owned cooperatives engage in both marketing and purchasing activities. The principal purpose of any cooperative association is to sell, buy, or furnish products, merchandise, or services, as the case may be, for its patrons at cost. In order further to reduce costs to their patrons, some marketing cooperatives engage in the first processing, warehousing, and transporting of farm products, and some purchasing cooperatives, for the same purpose and also in order to secure necessary supplies, engage in manufacturing operations and own and operate oil wells, refineries, fertilizer plants, and feed-processing plants.

Cooperative associations vary in their actual methods of operation. Generally, however, the marketing cooperative agrees to market all the agricultural products of the type handled by it produced and delivered to it by its patrons, and to pay to each patron the entire marketing proceeds after deduction of expenses. When a patron delivers products to the cooperative for sale, the amount to which he will finally be entitled cannot be known, so the cooperative pays to the patron a substantial part of the estimated sales price. At the end of the year, when the products have been sold and the costs determined, the cooperative distributes the remainder of the proceeds to its patrons in proportion to the products marketed for them. This distribution is called a patronage refund, but in reality it is further payment of the sales price. In addition to their selling, processing, warehousing, and other activities incident to the marketing of products to the best possible advantage, most farmers' marketing cooperatives employ laboratory and other experts for the purpose of improving the quality of their patrons' products, increasing efficiency in production, and informing members of current developments in production methods, types of product, and equipment.

A purchasing cooperative agrees to buy and deliver to its patrons farm supplies and other goods at cost. Since the actual cost of each purchase cannot be determined in advance, the cooperative usually charges and collects from the patron an amount more than sufficient to cover the expected cost price plus estimated operating expense. At the end of the accounting period the actual cost of goods purchased plus 
cost of operation is determined, and any excess amount collected from the patrons is returned to them in proportion to their purchases. The amount so returned to the patrons is a true patronage refund.

In American Shook Box Export Association v. Commissioner," the court said:

In order to be a true cooperative, however, the decisions emphasize that there must be a legal obligation on the part of the association ... to return to the members on a patronage basis, all funds received in excess of the cost of goods sold. Such an obligation may arise from the association's articles of incorporation, its by-laws, or some other contract. ${ }^{5}$

I would define a true cooperative as one which is legally obligated, by written agreement or by appropriate provisions of its articles of incorporation or by-laws or by the statute under which it is organized (I) to distribute to its members or patrons, or both, in proportion to their patronage, all of its income in excess of its costs of operation, except such as it is authorized to pay in limited dividends upon capital stock and to place in statutory or other necessary reserves, and (2) to allocate or credit all reserves (except consumable reserves) to the patrons who contributed to them, upon the same patronage basis. It is this type of true cooperative to which I refer when using the term "cooperative."

Cooperative associations are organized either on a capital stock or on a membership basis. In the capital-stock cooperatives exclusive voting control is in the common or membership stock and all eligible patrons must acquire at least one share, which may be paid for upon an ordinary subscription basis or by the application of patronage refunds. In most membership cooperatives the patron, if eligible, is required to pay for a membership (usually the fee is nominal) when he first patronizes the cooperative.

Cooperatives need capital, as do private business corporations. Indeed, some marketing cooperatives need more capital than private business corporations with which they may be in competition, because of their obligation to accept all products tendered by their members, regardless of market conditions. Such cooperatives cannot buy when market conditions are favorable and refuse to buy at other times. Carrying of large inventories and consequent unusual exposure are inevitable during certain periods and seasons.

Cooperatives generally finance themselves through the issuance of preference stock, bonds, notes, certificates of indebtedness, and bank borrowings, and the use of revolving and other reserves. A large part of the securities of cooperatives is sold to members and patrons in the usual fashion, except that sales are direct from the cooperative to the individual purchaser. It is practically impossible for a cooperative to offer a security which is attractive to the ordinary investor, because of the usual provisions of state statutes limiting dividends upon capital stock, prohibiting payment of cumulative dividends, requiring that control of the corporation shall always be in members (producer-members in farmer cooperatives), limiting

' 156 F. 2d 629 (C.C.A. 9th I946).

Id. at 630 . 
the class from which directors and officers may be chosen, and other less important restrictions. Thus cooperatives are practically compelled to secure their capital from their own patrons and members. The result is that this capital has been secured to a considerable extent from the reinvestment in capital securities of the cooperative by patrons of their share of the receipts of the cooperative. All the state statutes require cooperatives to distribute net income (after dividends on capital stock and after small required reserves) to patrons annually or oftener, and most of them expressly permit distributions to be made in capital securities. It is principally the methods used by cooperatives to finance their activities which give rise to the present bitter attacks upon the income-tax treatment accorded cooperatives by Congress, the Treasury Department, and the courts.

Since IgI6 the Internal Revenue Code has provided an exemption for farmer cooperatives fulfilling certain stated conditions. The Internal Revenue Code contains no other provisions specifically applicable to cooperatives, so that for income tax purposes there are only two classes of cooperatives, one class consisting of those wholly exempt from the payment of income taxes, and the other of those which are not exempt and which are subject to the same rules, regulations, and laws as private business corporations. Orderly treatment requires separate consideration of each class.

\section{Exempt Cooperattve Assoctations}

The exemption provisions applicable to cooperative associations appear in Section $\operatorname{ror}\left(\mathrm{I}_{2}\right)$ and (I3) of the Internal Revenue Code. ${ }^{6}$ Section ror (r3) is not particularly important here. Section $\operatorname{ror}(\mathrm{I} 2)$ is set forth in a footnote. ${ }^{7}$

The statute, in different form, was first enacted in Igr6 and has been amended on several occasions, but it has been in substantially the present form since $x 926 .^{8}$

It will be observed that the statute offers to certain farmer cooperatives a con-

53 STAr. 876, 26 U.S.C. §ror(12), (13) (1940).

' "Farmers', fruit growers', or like associations organized and operated on a cooperative basis (a) for the purpose of marketing the products of members or other producers, and turning back to them the proceeds of sales, less the necessary marketing expenses, on the basis of either the quantity or the value of the products furnished by them, or (b) for the purpose of purchasing supplies and equipment for the use of members or other persons, and turning over such supplies and equipment to them at actual cost, plus necessary expenses. Exemption shall not be denied any such association because it has capital stock, if the dividend rate of such stock is fixed at not to exceed the legal rate of interest in the State of incorporation or 8 per centum per annum, whichever is greater, on the value of the consideration for which the stock was issued, and if substantially all such stock (other than non-voting preferred stock, the owners of which are not entitled or permittod to participate, directly or indirectly, in the profits of the association, upon dissolution or otherwise, beyond the fixed dividends) is owned by producers who market their products or purchase their supplies and equipment through the association; nor shall exemption be denied any such association because there is accumulated and maintained by it a reserve required by State law or a reasonable reserve for any necessary purpose. Such an association may market the products of nonmembers in an amount the value of which does not exceed the value of the supplies and equipment purchased for members; provided the value of the purchases made for persons who are neither members nor producers does not exceed 15 per centum of the value of all its purchases. Business done for the United States or any of its agencies shall be disregarded in determining the right to exemption under this paragraph." Id. \$IOI(I2).

${ }^{8}$ Revenue Act of I92I, \$23I(II); Revenue Act of 1926, \$23I(12); Revenue Act of r928, \$23I. The Revenue Act of 1928 added what is $\$ 101(13)$ of the present Revenue Act. See also U. S. Treas. Reg. IIr, \$29.I0I (12), (13) (I943). 
ditional right to be exempted from the income tax. There are approximately ro,500 farmer cooperatives. Roughly, half of them have been granted exemption.

In order to qualify for exemption under this section a marketing association must limit its marketing operations to the marketing of the agricultural products of its members and patrons, pay to its patrons the proceeds of its sales less the necessary operating expenses on the basis of the products furnished by them, and limit its marketing of non-members' products to an amount not exceeding the products marketed for its members. A purchasing association must limit its operations so that the volume of goods purchased for non-members will not exceed the volume of goods bought for members, and so that purchases for those who are neither members nor producers will not exceed 15 per cent of total purchases. An association of either kind must be both organized and operated on a cooperative basis. All receipts in excess of actual cost must be turned back to patrons on a patronage basis. There may be no discrimination between members and non-members. Records must be kept in a manner that will disclose the interest of every patron in any patronage margins. If the cooperative has capital stock it may not pay dividends in excess of the legal rate of interest in the state of incorporation or 8 per cent, whichever is higher. In case of liquidation, stockholders may receive nothing in excess of the value of the consideration paid for the stock plus any unpaid declared dividends. Substantially all the voting stock must be owned by farmers who market their products or purchase their supplies and equipment through the cooperative. It must not maintain any reserves other than those required by the laws of the state of incorporation and reasonable reserves for necessary business purposes.

In order to have its right to exemption recognized a cooperative association must apply for and receive a letter of exemption from the Treasury Department. The exemption is effective only so long as the cooperative's form of organization and business practices conform to the statements made in the application and to the requirements of the Revenue Code. Those requirements are sufficiently onerous that many farmer cooperatives do not seek the exemption.

An exempt cooperative pays no federal income tax so long as it meets the statutory requirements. It is completely exempt from income tax in its operations. If it fails to comply with any of the statutory requirements, it loses the exemption and becomes subject to taxation as an ordinary corporation. There is no such thing as a partially exempt cooperative.

The exemption option is a special privilege extended to the agricultural industry. Most lawyers for farmer cooperatives make no attempt to justify the exemption upon legal grounds. It was granted by Congress because that body concluded that the best interests of the nation demanded that farmers be given this benefit in aid of their production of food for the nation. Or, as was stated by the Committee on Small Business of the House of Representatives,

The enactment and reenactment of Section $\operatorname{ror}(12)$ and (13) of the Internal Revenue 
Act appear to represent a continued attitude on the part of the Congress that the maintenance of a sound agricultural economy is necessary for the preservation of the national well-being. ${ }^{0}$

An exempt cooperative pays no income tax upon dividends paid on its capital stock or upon unallocated reserves created and maintained within the limitations of the exemption section. Practically, these are the only tax advantages of an exempt cooperative over a non-exempt cooperative. It has always been true that the limited dividends on capital stock paid by exempt cooperatives and their unallocated reserves are not of sufficient amount materially to affect the tax revenue, although they are of the greatest importance if such cooperatives are to be of substantial aid to agriculture.

The Undersecretary of the Treasury, A. Lee M. Wiggins, testifying before the Committee on Ways and Means of the House of Representatives in November, r947, stated that, although it was difficult to determine the exact figures, the Treasury would estimate that repeal of the exemption might increase federal revenue by $\$ 10,000,000$ to $\$ 20,000,000$ a year. ${ }^{10}$ The House Committee on Small Business, in the report mentioned above, found that no appreciable revenue would accrue to the Government if income taxes were levied upon the dividends on capital stock and amounts placed in reserves by exempt cooperatives. ${ }^{11}$ The Senate Committee on Agriculture and Forestry in a recent report stated:

Much of the current criticism to the effect that cooperatives should be taxed more heavily is in reality an attack against cooperatives as such by competing businesses rather than a criticism based upon the merits of the problem. The patronage dividends paid to farmers for savings made through cooperative marketing do not escape taxation, for the individual farmers must pay income taxes upon them. The tax loss to the Government is not great, and in so far as this loss is of concern, it should be noted that funds returned to members in the form of patronage dividends are not the property of the cooperatives but are part of the sales price or savings on the purchase price of individual transactions. In addition, the total amount of patronage dividends of farmer cooperatives is not large compared with the widespread purchase of supplies by employees of industry from the same or related corporations at wholesale prices on which the corporations pay no tax because of lack of profit from the transactions. ${ }^{12}$

In measuring the value of farmer cooperatives to the agricultural industry, the attitude of the farmer towards his cooperative must be kept in mind. To the ten million or more American farmers who belong to farmer cooperatives, it is one of the tools of their food factories, as important as their tractors, plows, automobiles, or other farm equipment. The prosperity of their cooperatives is directly reflected in their own economic status. Every farmer is a capitalist. $\mathrm{He}$ is in competition with the great marketing and distributing corporations of the country, both in mar-

- Frast Interm Report of the House Commitree on Smalc Business, April 9, 1946.

${ }^{10}$ Hearings before the Committee on Ways and Means on Proposed Revisons of the Internal Revenue Code, 8oth Cong., Ist Sess. I885 (I947).

12 See note 9 supra.

12 Report of the CoMmuttee on Agricultore and Forestry, Sen. Rep. No. 885, 80th Cong,, $2 d$ Sess. 42 (1948). 
keting his products and in purchasing his supplies. Operating alone he cannor be successful in his effort to meet such competition. Only by joining with other farmers can he compete in the market-places of this country. These are the conditions that brought farmer cooperatives into existence and moved Congress to pass laws for their encouragement. Through his cooperatives the farmer may be placed in a relatively equal competitive position with other capitalistic enterprises.

The exemption is valuable to the farmer cooperatives. They will continue to exist if the exemption is repealed, but their effectiveness as aids to the agricultural industry will be substantially reduced, partly because of the additional cost entailed by repeal, partly because of the increased operating, financing, and administrative burdens, and partly because field and expert services now given their members would be curtailed. There is no reason to believe that the situation of the farmer in the period which lies ahead will be any different from his situation in any other post-war period, with one exception-the demands for his products will be far greater than ever before. The farm population is diminishing, but the number of people for whom the agricultural industry must supply the absolute necessities of life, both here and abroad, is rapidly increasing. The cost of every phase of farm operation has sharply increased. Reduction in those costs will lag far behind the inevitable reduction in the price of farm products. Repeal of the exemption would react badly among farmers, and I think the welfare of the nation requires that no unnecessary action be taken which might have that effect. The production of adequate food and fibre supplies is a matter of paramount importance to the people of this country. Production of government revenue is also important. But the insignificant amount of revenue involved is not worth any risk whatever that the greater effort might be impaired. I believe we should aid Europe. We talk about expending twenty billions of dollars for that purpose. I cannot understand a philosophy which at the same time cavils at foregoing a few million dollars of government revenue to aid in the continuance of an adequate food and fibre supply for our own people.

\section{Non-Exempt Gooperattve Associations}

The provisions of the Internal Revenue Code applicable to ordinary business corporations apply in their full extent to non-exempt cooperatives. There is no statutory provision which gives to such cooperatives a right to income-tax treatment different from that given to any other business corporation, nor do court decisions or departmental rulings create any such right. Non-exempt cooperatives pay income taxes on the same basis as any other non-exempt corporation. They do pay far lower income taxes in dollars than ordinary business corporations, but that fact is due wholly to the difference between the two methods of doing business. Cooperatives have income. Our whole theory of the federal income tax, however, is that it is a tax only upon profits and not a tax upon gross income. The important question therefore is: Does a true cooperative have any corporate profit or taxable net income upon which it avoids income taxes? The answer to the question de- 
pends largely upon the treatment to be accorded obligatory patronage distributions.

Analysis shows that patronage distributions of a true cooperative are not profits of the corporation and that such distributions must be excluded in determining its net taxable income. (The term "excluded" rather than "deducted" is used because such distributions do not and should not enter into the income account of the cooperative at any time.) This is the position to which the Treasury Department has adhered for many years, and there can be little dispute that the courts have adopted the same view. The position of the Treasury Department is perhaps best stated in the following quotation from a memorandum of the general counsel:

So-called patronage dividends have long been recognized by the Bureau to be rebates on purchases made in the case of a cooperative purchasing organization or an additional cost of goods sold in the case of a cooperative marketing organization when paid with respect to purchases made by or sales made on account of the distributees. For purposes of administration of the Federal income tax laws, such distributions have been treated as deductions in determining the taxable net income of the distributing cooperative organization. Such distributions, however, when made pursuant to a prior agreement between the cooperative organization and its patrons, are more properly to be treated as exclusions from gross income of the cooperative organization (I.T. I499; S.M. 2595; G.C.M. 12393). It follows, therefore, that such patronage dividends, rebates, or refunds due patrons of a cooperative organization are not profits of the cooperative organization notwithstanding the amount due such patrons cannot be determined until after the closing of the books of the cooperative organization for a particular taxable period.13

This view has been approved by the Board of Tax Appeals..$^{14}$ In Midland Cooperative Wholesale v. Commissioner, ${ }^{16}$ the Board of Tax Appeals said:

... there is no ... statutory provision for the deduction of patronage dividends from the gross income of a cooperative association. Such deductions have been allowed by the Treasury Department, however, in the interest of substantial justice to such associations. Justification for such allowance rests in the fact that such so-called dividends are in reality rebates upon business transacted by the association with members rather than true income. ${ }^{16}$

The prevailing rule in the federal courts 17 is stated in Uniform Printing \& Supply Company v. Commissioner ${ }^{18}$ as follows:

If it [the distribution to patrons] was a refund or rebate to customers, it was not part of petitioner's taxable income, for the sum should have been included in the stockholders' [patrons'] taxable incomes.

18 G.C.M. I7895, Cum. Butr. 1937-I, 56, and see I. T. 3208, Cum. BuLl. 1938-2, 127.

14 Anamosa Farmers Creamery Co., 13 B.T.A. 907 (1928); Farmers Union Cooperative Ass'n, 13 B.T.A. 969 (1928); Grey Bull Corporation, 27 B.T.A. 853 (I933); Midland Cooperative Wholesale, 44 B.T.A. (194I); United Cooperatives, Inc., 4 T.C. 93 (1944); California Pine Box Distributors, P-H 1943 TC Mem. Dec. Serv. Par. 43,365 (1943).

15 44 B.T.A. 824 (I94r).

10 Id. at 830 .

${ }^{17}$ Cf. San Joaquin Valley Poultry Producers Ass'n v. Commissioner, 136 F. 2d 382 (C.C.A. 9th 1943); Midland Cooperative Wholesale v. Ickes, 125 F. 2d 618 (C.C.A. 8th 1942), cert. denied, 316 U. S. 673 (1942).

${ }^{18} 88$ F. 2d 75 (C.C.A. 7th 1937). 
Had the taxpayer given a customer (whether stockholder or outsider) a discount promptly after filling the order, no one would call it a dividend. If a rebate were given promptly upon the customer's business reaching a certain volume, the same conclusion as to its character would follow. To make cost estimates and adjust them at or near the end of each year returning the excess payment to the customer should not change the reasoning which leads to this conclusion. Nor should the fact that the customer is a stockholder materially affect the result.

It is true the taxpayer is not a non-profit corporation in a legal sense. It is subject to a tax upon the profits by it made. Nevertheless, net profits in its case must depend upon the facts. Payment to the customers, who are also taxpayers, of sums called refunds based upon the volume of business transacted and in no way dependent upon stock ownership, is the determinative factor. ${ }^{19}$

It is admitted that earnings of a cooperative on the business of patrons to whom there is no contractual obligation to make refunds are profits of the corporation and taxable as such, and of course the cooperatives admit that amounts paid to stockholders as dividends upon capital stock represent corporate profits which are taxable to the cooperative.

It is not necessary that patronage distributions be made in cash. If paid in money or its equivalent-capital stock, certificates of indebtedness, or notes-the distribution must be excluded. ${ }^{20}$ Although there has been criticism of this rule, there is little ground for it. The Treasury Department has always allowed ordinary corporations to deduct bonuses, salaries, or other operating expenses paid in corporate securities. Dividends upon capital stock so paid are treated as cash payments for the purposes of Section 102 of the Revenue Code. For tax purposes there would seem to be little doubt as to either the propriety or the fairness of the rule.

There is perhaps some room for doubt concerning the right of a cooperative to exclude net margins distributed to capital reserves and credited or allocated to patrons. The Treasury Department rule is that such distribution, if a certificate of interest or prompt notice of distribution is given to the patron, is excludable. ${ }^{21}$ On the theory that distributions so made pursuant to contractual authority are actually capital contributions by the contributing patrons, the ruling is legally sound; but the conclusion is based upon two assumptions, which might be called constructive receipt and constructive reinvestment, and is not altogether satisfactory. The decision of the Board of Tax Appeals ${ }^{22}$ holding such reserves to be excludable is based upon the fact that the reserves there involved were withdrawable at the will of the patron, so that the reserve was in fact a credit or payment. Actually, most of such reserves are not subject to withdrawal by the patron.

\footnotetext{
${ }^{10} I d$. at 76 .

${ }^{20}$ San Joaquin Valley Poultry Producers Ass'n v. Commissoner, r36 F. 2d 382 (C.C.A. 9th 1943); Midland Cooperative Wholesale, 44 B.T.A. 824 (r94I); United Cooperatives, Ine., 4 T.C. 93 (1944); G.C.M. 17895 CuM. Buzl. 1937-1, 56 and I.T. 3208, CuM. Bull. 1938-2, 127.

${ }^{21}$ See letters from Commissioner to National Council of Farmer Cooperatives in Hearings before Committee on Ways and Means on Proposed Revisions of the Internal Revenue Code, 8osh Cong., xst. Sess. 2619,2620 (1947).

${ }^{22}$ Midland Cooperative Wholesale, 44 B.T.A. 824 (I94I).
} 
Should Congress tax patronage distributions, assuming that it has power to do so? The principal argument for change is that present income-tax treatment of cooperatives gives them an unfair competitive advantage in their buying and selling operations over other forms of business organizations, such as business corporations, partnerships, and individual proprietorships. The non-exempt cooperative is, of course, treated for all practical purposes as a partnership or as an individual proprietorship. In each only one tax is paid. A majority of the private businesses in this country, and especially of those which compete with cooperatives, are partnerships and individual proprietorships. Whether or not a competitive advantage over corporate competitors may be derived from income-tax treatment, certainly the cooperatives have no material advantage over these competitors. Any competitive advantage the cooperatives may have over an ordinary business corporation is not due to its tax status. The marketing cooperative sells the products of its members in the same market as do the private selling agencies, and usually for about the same prices. It may reach the market with lower costs than the private agencies, but, if so, this is not attributable to the fact that the cooperative is not required to pay a tax upon its patronage refunds. Similarly, the purchasing cooperative cannot obtain męrchandise at lower prices than do ordinary wholesalers or retailers merely because it need pay no income tax upon the savings effected on resale. If the purchasing cooperative makes greater savings than its competitors, the greater savings are not attributable to the fact that the cooperative will pay no income tax upon the savings. Income taxes subsequently payable upon profits or savings realized do not determine the amount of the profit or saving. The tax status of a cooperative, therefore, has no direct bearing upon any competitive advantage which it may have in its buying and selling operations.

It is a novel suggestion that the taxing power ought to be used to level off competitive advantages. Stock insurance companies are taxed on a basis different from that of mutual insurance companies. Building and loan associations, although today in active competition with commercial banks, are taxed on a basis different from that of banks. Other illustrations could be given. Perhaps the stock insurance companies and the banks feel that no competitive advantage arises from the tax treatment of their competitors. In any event, they have not urged a change in the Internal Revenue Code designed to level off their competition. Furthermore, this method of minimizing income taxes is open to all other forms of business enterprise and is often used by them. So-called private business establishments frequently adjust prices of both sales and purchases after transactions have been consummated. In many cases of renegotiation, discount rates are revised to reflect reduced costs or results of cumulative quantity sales or purchases in a good period or season. In practice such adjustments are considered as costs of operation to the business enterprise and not as distributions of earnings. Any other business establishment that is willing to serve its customers at cost without making a profit for its stockholders can avoid the payment of income taxes on amounts refunded or rebated in that manner. 
Another argument which has been advanced against the present tax treatment of cooperatives is that patronage refunds represent money earned by the same processes of buying, selling, and manufacturing that are employed by other forms of business organizations, and that the taxability of earnings should depend on the way in which those earnings are created and not upon the disposition that is made of them; that there is nothing in the mechanical organization or plan of operation of a cooperative to differentiate it from a business corporation from the tax angle; that patronage refunds represent a distribution of earnings by the corporation itself, and so should be taxed as income of the cooperative; and that the existing exclusion of patronage refunds is based upon a misunderstanding of their true nature. The complete answer to this argument is that a cooperative is bound by a preexisting contractual obligation to return to its patrons, on a patronage basis, the entire net proceeds of its operations, less dividends payable on capital stock and amounts set aside for reserves; that in the case of a marketing cooperative such payment represents the final settlement of the prices the patron is entitled to receive for his products, and in the case of a purchasing cooperative these payments represent a reduction in cost to the patron of the goods purchased by him through the cooperative; and that at no time does any part of such net proceeds either belong to the cooperative or constitute profit or income to it, except that earnings on the business of patrons to whom there is no such obligation do belong to the cooperative and are subject to taxation.

Both the preceding arguments, and as a matter of fact practically all arguments against the present method of taxing cooperatives, stem from the present double tax imposed upon the profits of ordinary business corporations. Most critics, lawyers, businessmen, and farmers agree that this double taxation is wrong, but if patronage refunds were taxed to the cooperative there would be even more vicious double taxation and extension of the wrong.

Should a cooperative be allowed to exclud: jatronage refunds which are distributed in the form of capital securities? Unquestionably the practice enables the cooperatives to build up capital more easily than would otherwise be possible, but payment of corporate obligations with corporate securities has long been a recognized practice. If the recipient agrees that the security is worth what is due him, there is complete payment. Practically, as the United States Tax Court said in the United Cooperatives case:

The result of the procedure set up by petitioner's bylaws was as if the stockholder member who was under obligation to purchase additional stock had reeerved, in cash, the "patronage dividend" and had thereupon applied this sum to the payment of his stock. The stock, when thus paid and issued to him, was not in the nature of a stock dividend, but represented an additional investment on his part to the capital of the corporation out of his savings from the annual transactions with petitioner. ${ }^{23}$

As to the claim that cooperatives should not be permitted to exclude or deduct ${ }_{28} 4$ T.C. 93, ro8 (1944). 
patronage refunds distributed or allocated to reserves, where the only evidence of the distribution received by the patron is a so-called certificate of interest or a mere notice of the distribution and allocation, the cooperative argument for exclusion is that these reserves are owned by the patrons to whom they have been allocated, and in any event they represent capital contributions made by the patrons pursuant to a valid contract between the patron and the cooperative. Notwithstanding the validity of this argument, it is somewhat doubtful that there is constructive receipt by the patron. It must be admitted that in all probability many patrons do not include such distributions in calculating their own income tax, so that some income, especially in farmer cooperatives, probably escapes taxation entirely.

One other minor criticism of cooperatives requires a word. It is charged that many patrons of cooperatives have no knowledge of or voice in the manner in which patronage refunds will be made. In a true cooperative there is no legal basis for the charge. The patron either has a formal written agreement with the cooperative covering the point, or, by notice, actual or constructive, is charged with knowledge of the provisions of the articles of incorporation or by-laws of the cooperative, which clearly define the manner in which distributions will be made. Where the formal contract does not exist, patrons as a practical matter may fix the pattern through their control of the corporation. The charge, even if true, has little or nothing to do with the tax problem. In any event, I think few cooperatives would object to a requirement of written revocable authority from individual patrons specifying the manner in which patronage distributions should be made, as a prerequisite to the exclusion or deduction of patronage refunds made in any form but cash.

There is grave doubt whether Congress has power to tax patronage distributions even if it were willing to change present conceptions as to the character of taxable income. Clearly, income belonging to one person cannot be taxed to another; taxable income is only profit income, ${ }^{24}$ and Congress cannot tax as income that which is not income. ${ }^{25}$ If the income of a cooperative belongs to its patrons and is income to them and not to the cooperative, then it cannot constitutionally be taxed to the cooperative.

The contract between the cooperative and its patron fixes the price to be paid by or charged to the patron. It thereby imposes upon the cooperative a liability to adjust the price by means of the payment of patronage refunds when costs of operation are finally determined. Under any income-tax system which does not tax expenses of doing business, that liability, when paid or accrued, must be excluded from taxable income.

Assuming for the purpose of argument that the cooperative does have net-profit income, the liability first described is not different in principle from the obviously deductible liability which an ordinary business corporation may assume by its prior

"Eisner v. Macomber, 253 U. S. I89 (I9I9); Commissioner v. Wilcox, 327 U. S. 404 (I946).

${ }^{25}$ Helvering v. Edison Bros. Stores, Inc, r33 F. 2 d 575 (C.C.A. 8th I943), cert. denied, 3I9 U. S. 752 (1943). 
agreement to pay officers or employees compensation measured by corporate earnings or by percentage commissions. In the one case the price of goods is later adjusted to conform to the prior agreement, and in the other case the price of services is so adjusted after performance.

In relation to this constitutional point the question whether a cooperative is merely an agent or trustee for its members and patrons becomes particularly important. Many courts have held that a cooperative, despite the use of ordinary terms of sale and purchase in its contracts, is merely an agent. ${ }^{20}$ Notwithstanding the various arguments advanced against the agency theory, it is a fact that in the Bowles decision eighteen cases in which courts supported the agency theory are cited. ${ }^{27}$ Practically all of these cases involved marketing cooperatives. Where a cooperative deals only with its members, the agency theory, in my judgment, is sound. Where, however, it deals with both members and non-members, there are fewer of the incidents of a true agency. The California courts and the Circuit Court of Appeals of the Ninth Circuit have uniformly held that a cooperative organized under the California cooperative statute acts in a fiduciary capacity and holds all of its net income as trustee for its patrons. ${ }^{28}$ The California statute expressly provides that cooperatives organized under it shall be non-profit corporations, but otherwise differs little from the usual state statute. The statute does not weaken these cases as authorities when applied to other cooperatives, for a true cooperative is a non-profit corporation exactly as is the California cooperative.

If the contract liability theory be applied and distributions in securities or to capital reserves be considered payment of the liability and a capital reinvestment by the patron, or if either the agency or fiduciary theory be applied, patronage refunds distributed to patrons on the basis of their business with the cooperative, excluding earnings on the business of non-participating patrons, are not income of the cooperative within the meaning of the constitutional provision and cannot either be made such by congressional fiat or be taxed as such by Congress.

The cooperatives recognize that abuses probably exist with respect to both exempt and non-exempt cooperatives and their members. Abuses also exist with respect to ordinary business corporations, and cooperatives and their patrons, like those corporations and other citizens, make mistakes. Reserves of exempt cooperatives may not always be fully within the statutory allowance; some distributions of patronage refunds may escape taxation as income of the patron, and patronage distributions to capital reserves may escape tax entirely. If these abuses or loopholes exist, legislation to correct or prevent them is not necessary. Simple amendments of the Treasury Regulations can and would insure against them and secure to the Government its proper tax revenue.

${ }^{20}$ Bowles v. Inland Empire Dairy Ass'n, 53 F. Supp. 210 (E. D. Wash. 1943).

${ }^{27}$ Id. at 215.

${ }^{28}$ California and Hawaiian Sugar Refining Corp., Ltd. v. Commissioner, r6 63 F. 2d 531 (C.C.A. 9th 1947), cert. denied, February 1948. 